\title{
Earthquake Response of Multi-Storey Infilled Reinforced Concrete Buildings
}

\author{
Miloud Mouzzoun*, Abdelkader Cherrabi
}

Civil engineering department, Hassania School of Public Works, Casablanca, BP8108, Morocco

\begin{tabular}{l} 
A R T I C L E I N F O \\
\hline Article history: \\
Received: .22 June, 2020 \\
Accepted: 20 July, 2020 \\
Online: 25 August, 2020 \\
\hline Keywords: \\
Frame \\
Infill \\
Seismic \\
Time history \\
Pushover \\
Strut \\
\hline
\end{tabular}

\begin{abstract}
A B S T R A C T
The aim of this work is to study the effect of infill brick panels on the response of multistorey buildings under seismic loading. An eight storey building is investigated. The building is analysed under gravity and seismic loads. Infill panel is replaced by two struts according to FEMA306. Time history and pushover analyses are performed to assess seismic strength of the building. Simulations are performed by SAP2000. Numerical results show that behavior of bare and infill frames under lateral loading are too distinct. There is a change in the manner in which the infill frame carries the lateral loads.
\end{abstract}

\section{Introduction}

Concrete frames infilled by bricks are generally used as structural system for multi-storey buildings to carry gravity and lateral seismic loads. Past earthquakes, have indicate that infill panels change the structural response of buildings under seismic loads. Figures 1 and 2 show collapses caused by soft storey and short column effects. Structural behavior of infilled frames was studied by many authors [1]-[7]. The studies were concentrated on the response of infilled frames by masonry under horizontal loading. Experimental results indicate that masonry infills modify the structural behavior of the frame. There is a modification in the manner in which the frame carries the lateral loads. In this article the seismic effect of infill on structural response of buildings is investigated. For this purpose, a multi-storey framed building is studied. Infill panel is modeled by two concentric diagonal struts according to FEMA306 [8]. Numerical simulations are performed using the software analysis SAP2000.

\section{Material Nonlinearity}

\subsection{Concrete members}

Beams and columns are idealized as frame elements with two concentrated plastic hinges at the extremities. For pushover analysis, P-M3 hinge is assigned to the columns and M3 hinge is

"Corresponding Author: Miloud Mouzzoun, Hassania School of public works, Morocco, mouzzoun.mouloud@gmail.com assigned to the beams. The hinge parameters are calculated according to FEMA356 [10].
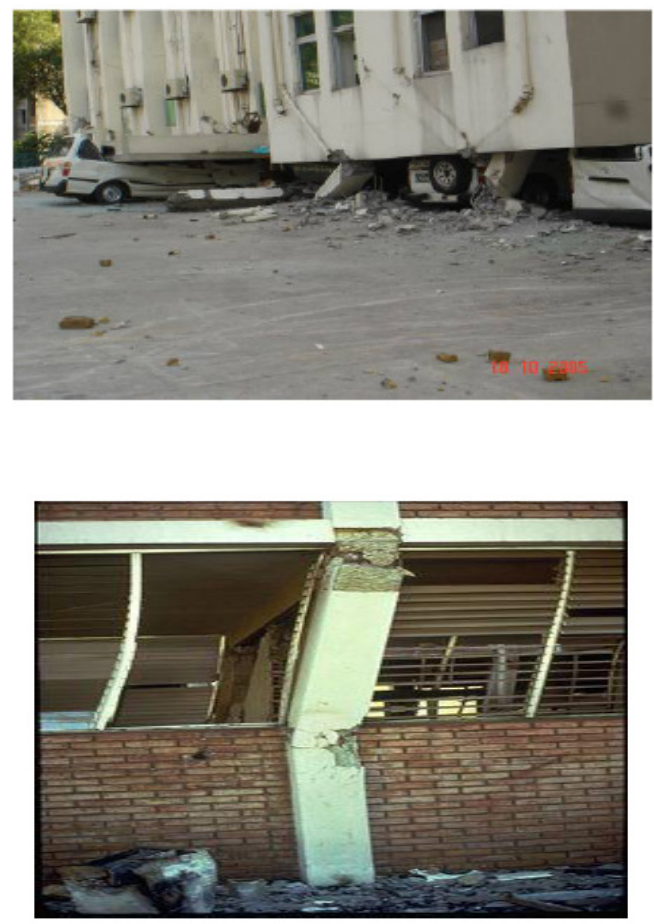

Figure 2: Short column mechanism [9] 

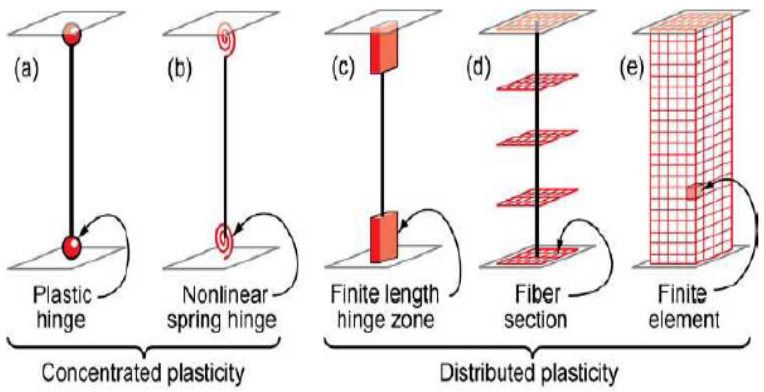

Figure 3: Introduction of material nonlinearity in concrete members [11]

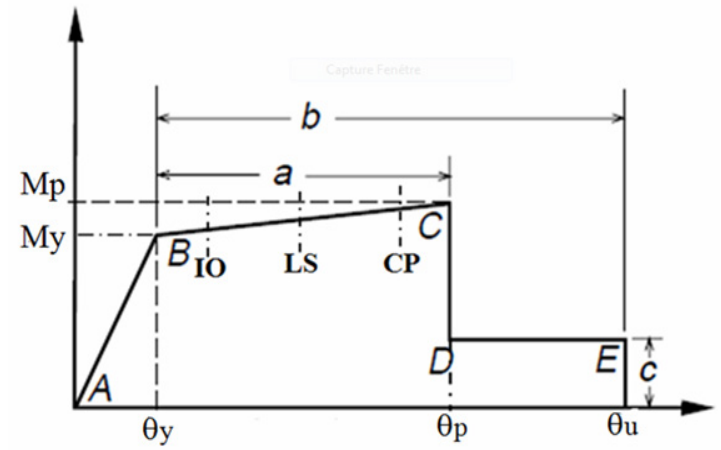

Figure 4: behavior of plastic hinge

\subsection{Masonry infill wall}

When lateral seismic forces are applied, infilled frame is replaced by two struts as shown in figure 5 . The strut doesn't support any tension, it carries only compression loads. Strut width $\mathrm{W}$ is calculated by the equation (1).

$$
\begin{gathered}
w=0.175 d\left(\lambda H_{c}\right)^{-0.4} \\
\lambda=\sqrt[4]{\frac{E_{m} t \sin 2 \theta}{4 E_{c} I_{c} H_{m}}} \\
\theta=\tan ^{-1} \frac{H_{m}}{L_{m}}
\end{gathered}
$$

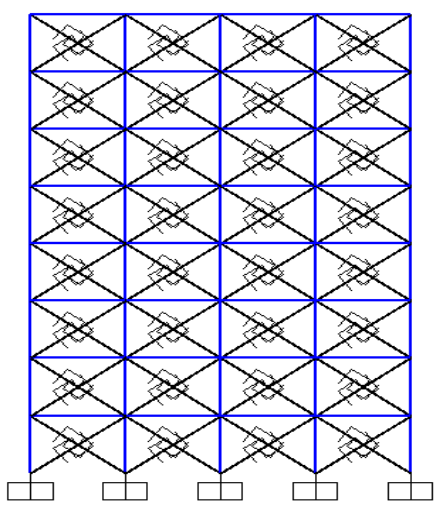

Figure 5: Frame with equivalent diagonal struts

\section{Numerical investigations}

The building studied here is an eight storey framed building, having 20 meters in the transversal direction and 25 meters in the longitudinal direction. Each storey height is $3 \mathrm{~m}$. The beams sections are $25 \mathrm{~cm} \times 40 \mathrm{~cm}$; slabs thicknesses are $14 \mathrm{~cm}$. The columns sections vary from $30 \mathrm{~cm} \times 30 \mathrm{~cm}$ to $45 \mathrm{~cm} \times 45 \mathrm{~cm}$. Building is analyzed under gravity and lateral seismic loads. Time history and Pushover analyses are performed by SAP2000 [12].

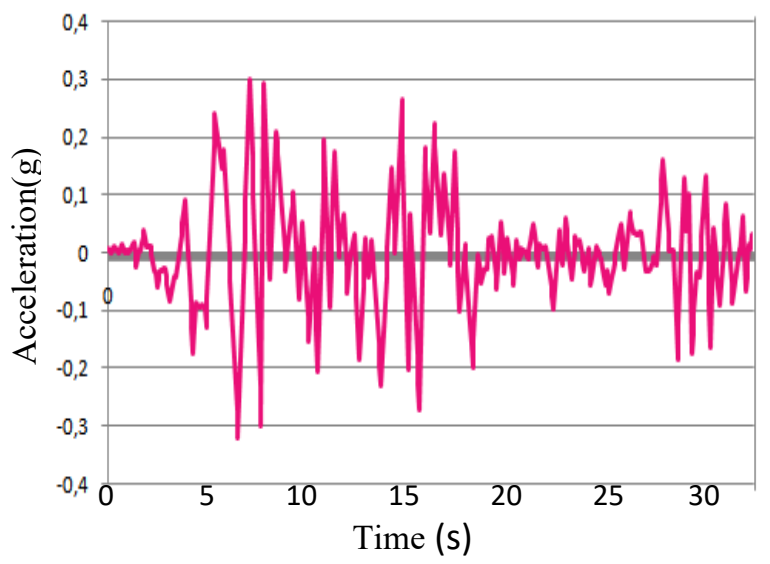

Figure 6: Elcentro Earthquake ground motion

\section{Results and discussion}

\subsection{Periods of vibration}

In the table 1, the periods of vibration of infill and bare frames are presented. It's found that introduction of infill walls reduces significantly the vibration periods.

Table 1: Natural periods of vibration

\begin{tabular}{|c|c|c|}
\hline Mode Number & Infill frame & Bare frame \\
\hline 1 & 0.265 & 0.498 \\
\hline 2 & 0.092 & 0.166 \\
\hline 3 & 0.054 & 0.089 \\
\hline 4 & 0.037 & 0.055 \\
\hline 5 & 0.028 & 0.039 \\
\hline 6 & 0.027 & 0.029 \\
\hline
\end{tabular}

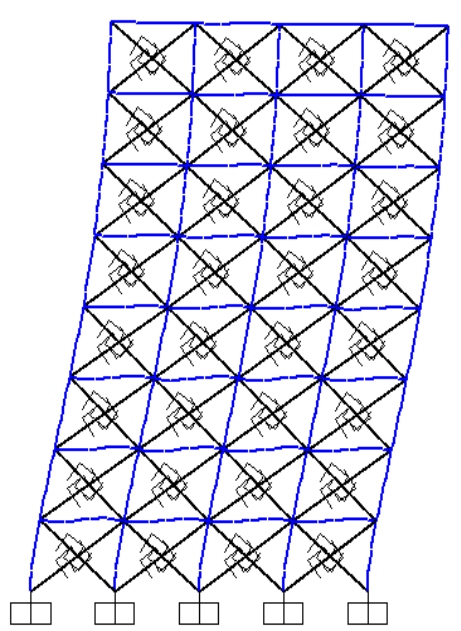

Figure 7: First mode of vibration of infill frame. $\mathrm{T}=0.265 \mathrm{~s}$ 


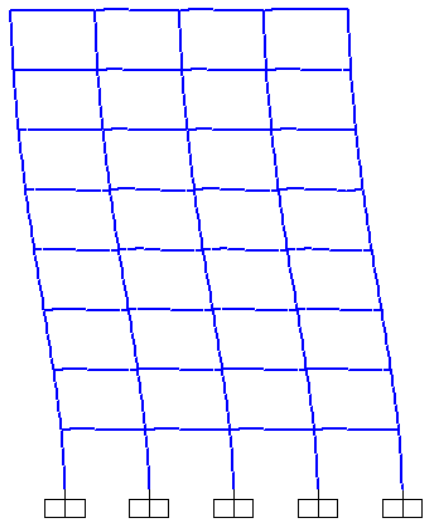

Figure 8: First mode of vibration of bare frame. $\mathrm{T}=0.498 \mathrm{~s}$

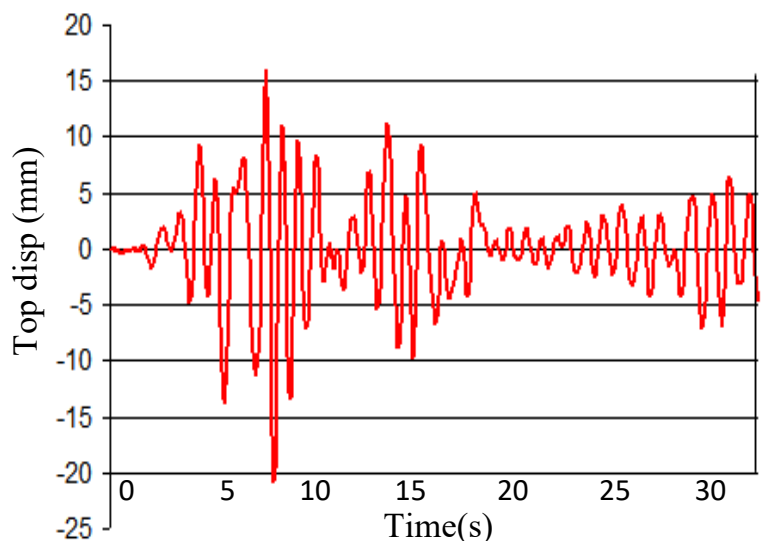

Figure 9: Top displacement time history. Infill frame

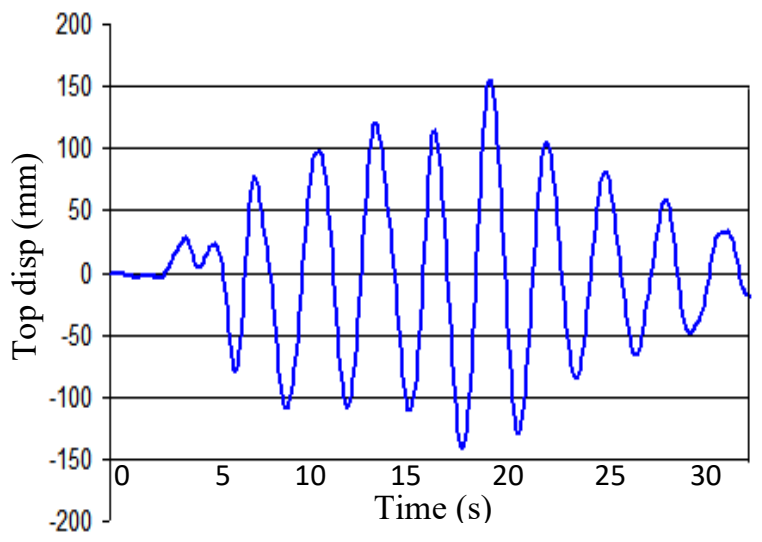

Figure 10: Top displacement time history. Bare frame

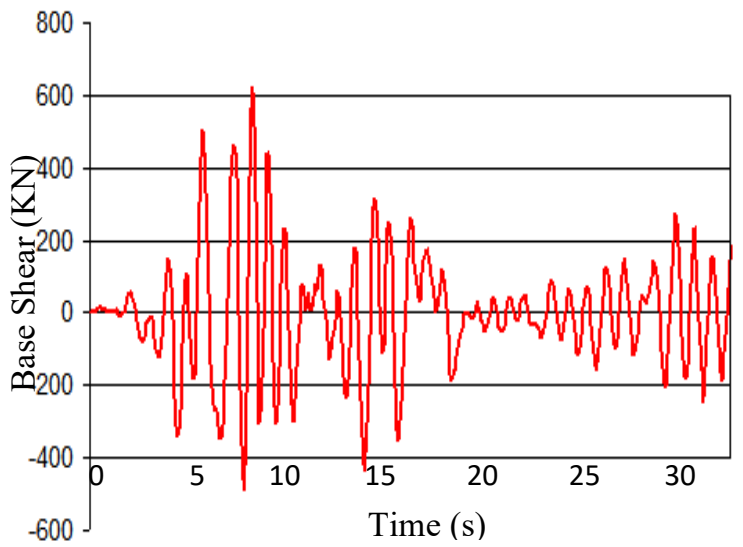

Figure 11: Base shear time history. Infill frame

\subsection{Top displacement and base shear}

Base shear and roof displacement time histories are shown in the figures 9, 10, 11 and 12 . The results show that top displacement decreases and base shear increases when infill panels were introduced in the model by diagonal strut concept.

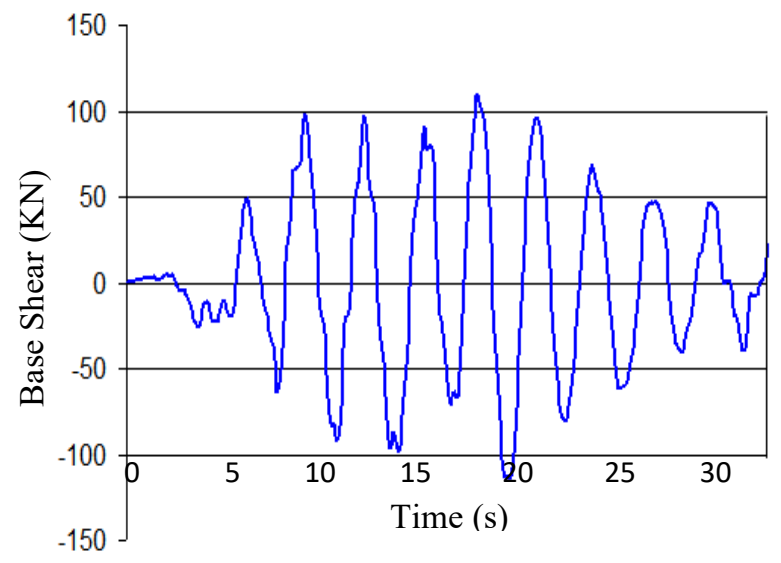

Figure 12: Base shear time history. Bare frame

\subsection{Bending moments and shear forces}

In the tables 2 to 5 , we present the results of internal forces. The obtained results show that there is a great reduction in the values of bending moments and shear forces when infill wall is introduced in the structural model.

Table 2: Bending moments in the columns

\begin{tabular}{|c|c|c|}
\hline \multirow{2}{*}{ Storey } & Bare frame & Infill frame \\
\cline { 2 - 3 } & M(KN.m) & M(KN.m) \\
\hline $8^{\circ}$ & 68,02 & 23,81 \\
\hline $7^{\circ}$ & 103,71 & 37,57 \\
\hline $6^{\circ}$ & 153,61 & 63,17 \\
\hline $5^{\circ}$ & 168,90 & 70,58 \\
\hline $4^{\circ}$ & 171,49 & 75,95 \\
\hline $3^{\circ}$ & 215,12 & 82,65 \\
\hline $2^{\circ}$ & 298,60 & 132,40 \\
\hline $1^{\circ}$ & 450,97 & 280,97 \\
\hline
\end{tabular}

Table 3: Shear forces in the columns

\begin{tabular}{|c|c|c|}
\hline \multirow{2}{*}{ Storey } & Bare frame & Infill frame \\
\cline { 2 - 3 } & $\mathrm{V}(\mathrm{KN})$ & $\mathrm{V}(\mathrm{KN})$ \\
\hline $8^{\circ}$ & 33,15 & 11,42 \\
\hline $7^{\circ}$ & 54,81 & 18,86 \\
\hline $6^{\circ}$ & 81,87 & 32,33 \\
\hline $5^{\circ}$ & 97,47 & 39,07 \\
\hline $4^{\circ}$ & 109,03 & 43,81 \\
\hline $3^{\circ}$ & 122,19 & 55,08 \\
\hline $2^{\circ}$ & 122,45 & 62,65 \\
\hline $1^{\circ}$ & 117,48 & 86,27 \\
\hline
\end{tabular}


M. Mouzzoun et al. / Advances in Science, Technology and Engineering Systems Journal Vol. 5, No. 4, 633-637 (2020)

Table 4: Shear forces in the beams

\begin{tabular}{|c|c|c|}
\hline \multirow{2}{*}{ Beam } & Bare frame & Infill frame \\
\cline { 2 - 3 } & $\mathrm{V}(\mathrm{KN})$ & $\mathrm{V}(\mathrm{KN})$ \\
\hline B1 & 104,71 & 60,50 \\
\hline B2 & 107,74 & 61,64 \\
\hline B3 & 104,68 & 61,59 \\
\hline B4 & 105,48 & 61,44 \\
\hline
\end{tabular}

Table 5: Bending moments in the beams

\begin{tabular}{|c|c|c|}
\hline \multirow{2}{*}{ Beam } & Bare frame & Infill frame \\
\cline { 2 - 3 } & M (KN.m) & M (KN.m) \\
\hline B1 & 166,02 & 78,63 \\
\hline B2 & 168,16 & 81,90 \\
\hline B3 & 168,04 & 81,86 \\
\hline B4 & 172,27 & 82,07 \\
\hline
\end{tabular}

\subsection{Seismic performance}

Pushover analyses are carried out for infill and bare frames. The obtained pushover curves are superposed with the seismic demand curves to obtain the performance point. Two seismic demands are considered; moderate shaking with design acceleration $\mathrm{A}=0.16 \mathrm{~g}$ and high shaking with design acceleration $\mathrm{A}=0.20 \mathrm{~g}$.

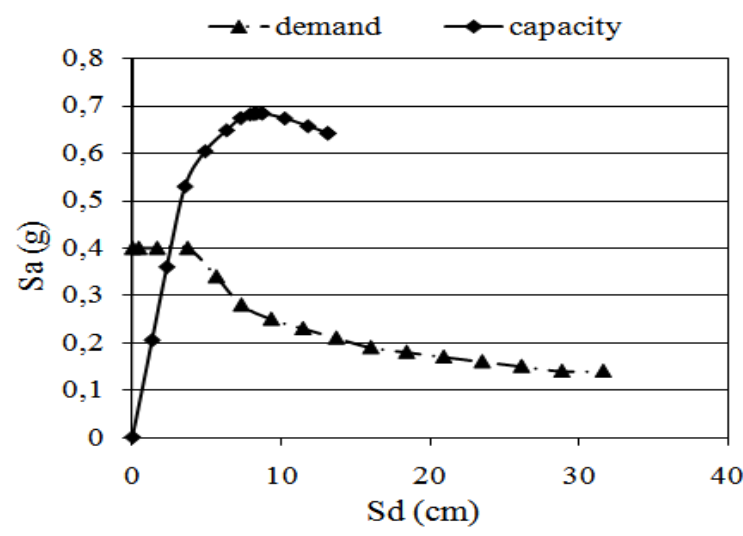

Figure 13: Seismic performance of infill frame under moderate shaking

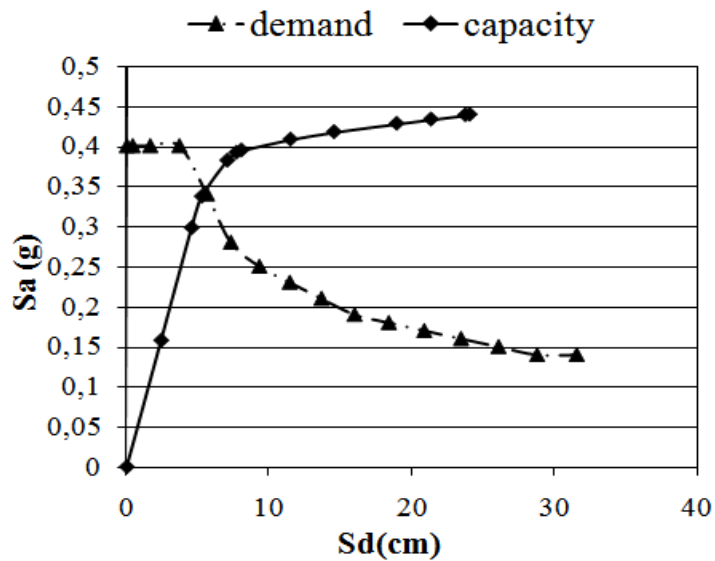

Figure 14: Seismic performance of bare frame under moderate shaking

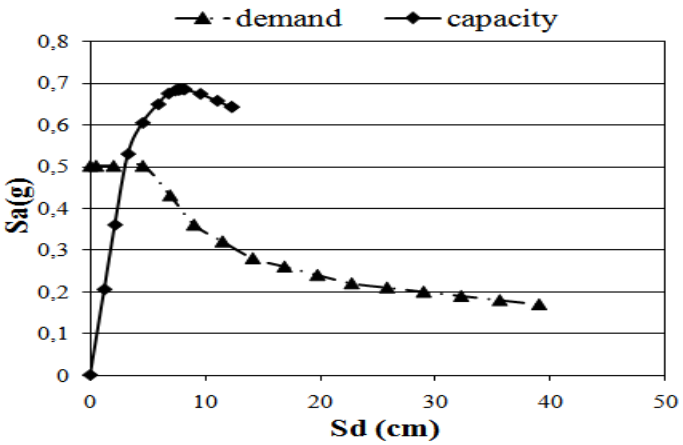

Figure 15: Seismic performance of infill frame under high shaking

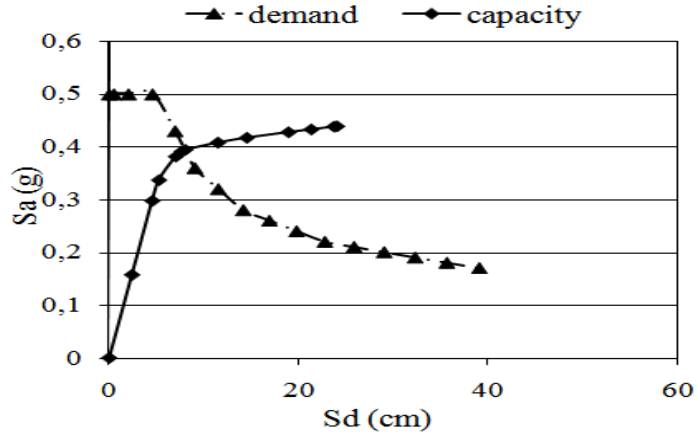

Figure 16: Seismic performance of bare frame under high shaking

\subsection{Lateral storey displacements}

The seismic demands for infill and bare frames under moderate and high shaking are presented in the figures 17 to 20 . The results show that infill frame performs well compared with bare frame.

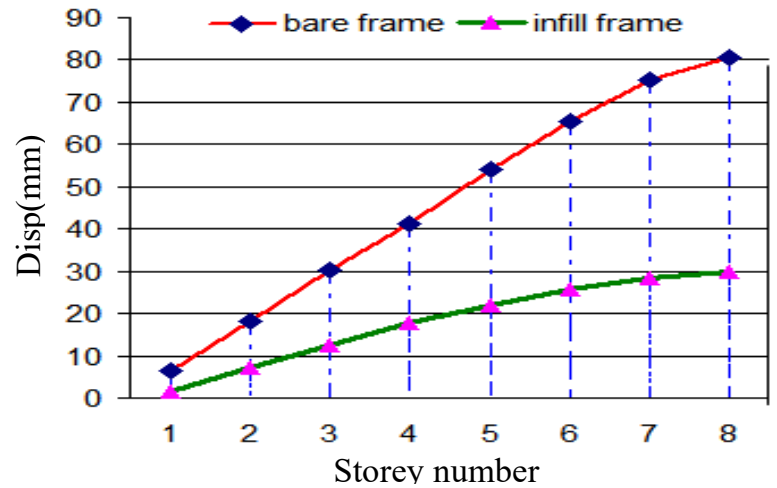

Figure 17: Lateral story displacements under moderate shaking

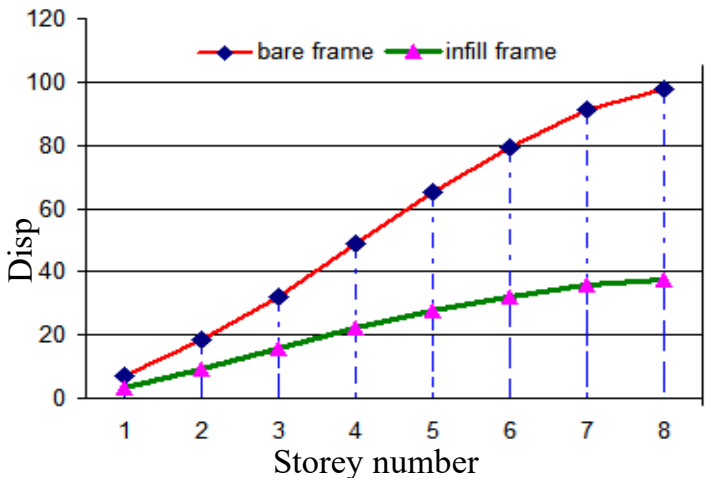

Figure 18: Lateral story displacements under high shaking 


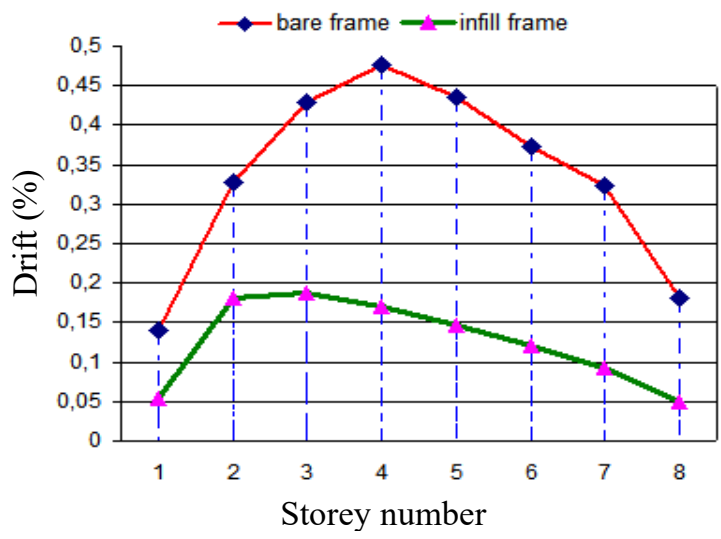

Figure 19: Inter-storey drifts under moderate shaking

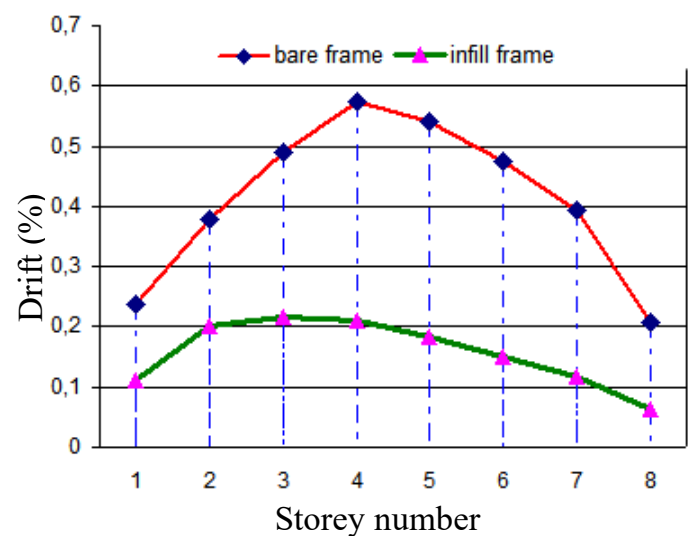

Figure 20: Inter-storey drifts under high shaking

\section{Conclusion}

The structural behavior of multi-storey buildings with infill panels under earthquake motion was investigated. The essential results are:

- Results show that natural periods of bare frame are greater than those of infill frame. Therefore, frame analysis without infill idealization underestimates the lateral shear design.

- Numerical simulations indicate that infill walls change considerably the internal forces. Maximum bending moments and shear forces of frame without infill are greater than those of infill frame.

- Pushover analysis shows that infill walls increase both lateral strength and stiffness of the building. Therefore, the seismic vulnerability of infilled building will be significantly reduced.

- Pushover analysis indicates that seismic performance of infill frame is largely superior to that of bare frame under different seismic intensities.

- Investigation results show that there is a change in the manner in which the infill frame carries the lateral loads. Diagonal strut concept of infill transforms the flexible frame into braced frame and then the values of internal forces will be changed.

Finally, this study has highlighted the influence of uniform infills on the earthquake response. Infill walls have a significant influence under seismic loads. Neglecting infills in the structural analysis is note a safe way. In perspective, it seems important to study the seismic effect of irregular configurations of infill panels, in order to prevent their unfavorable effects as in the case of soft storey and short column failures.

\section{Conflict of Interest}

The authors declare no conflict of interest.

\section{References}

[1] R.J. Mainstone, "on the stiffness and strength of lnfilled frames" Proceedings of the Institution of the Civil Engineers, 49(2). 1971. https://doi.org/10.1680/iicep.1971.6267.

[2] D.V. Malick, RT Severn, "dynamic characteristics of infilled frames" Proceedings of the Institution of the Civil Engineers, 39(2). 1968. https://doi.org/10.1680/iicep.1968.8091.

[3] B. Stafford, C. Carter, "A method for analysis for infilled frames" Proceedings of Institution of Civil Engineers, No. 7218, 31-48, 1969 https://doi.org/10.1680/iicep.1969.7290.

[4] A.B. Mehrabi, P.B.Shing, M.P.Schuller, J.L.Noland, "Experimental Evaluation of Masonry-Infilled RC Frames" ASCE Journal of Structural Engineering, 122(3), 228-237, 1996. https://doi.org/10.1061/(ASCE)07339445(1997)123:5(604)

[5] P. Negro, A. Colombo, "Irregularities induced by non structural masonry panels in framed buildings" Engineering Structures. 19(7), 576-585.1997. https://doi.org/10.1016/S0141-0296(96)00115-0.

[6] G. Al-Chaar, Evaluating strength and stiffness of unreinforced masonry structures. US Army Corps of Engineers. Construction Engineering Research Laboratories, 2002.

[7] A.Hashemi, K.M.Mosalam, "Shake-Table Experiment on Reinforced Concrete Structure Containing Masonry Infill Wall|" Journal of Earthquake Engineering and Structural Dynamics. 14(35), 1827-1852, 2006. https://doi.org/10.1002/eqe.612.

[8] FEMA306, Evaluation of Earthquake Damaged Concrete and Masonry Wall Buildings, Basic Procedures Manual, Federal Emergency Management Agency, 1999.

[9] M.Mouzzoun, "Seismic behaviour of reinforced concrete frame buildings with masonry infill", $\mathrm{PhD}$ thesis, Mohammadia School of engineers, Morocco, 2015.

[10] FEMA356, Federal Emergency Management Agency, NEHRP recommended Provisions for Seismic Regulations for New Buildings and Other Structures, 2000.

[11] ATC40, Applied Technology Council, Partnership for Response, and United States. Federal Emergency Management Agency. Evaluation of Earthquake Damaged Concrete and Masonry Wall Buildings: Basic Procedures Manual, 1999.

[12] CSI, Analysis Reference Manual for SAP2000, ETABS and SAFE, Computers and Structures, Inc. Berkeley, California, USA, 2005 